\title{
BRAND SOCIAL RESPONSIBILITY DAN CORPORATE SOCIAL RESPONSIBILTY DALAM RANGKA MENINGKATKAN REPUTASI DAN DAYA SAING ORGANISASI
}

\author{
Umu Khouroh ${ }^{1}$, Fatima Abdullah ${ }^{1}$ \\ ${ }^{1}$ Fakultas Ekonomi dan Bisnis Universitas Merdeka Malang
}

\begin{abstract}
:
The objective of this research is to examine the effects of Brand Social Responsibility (BSR) and Corporate Social Responsibility (CSR) on the reputation and competitiveness of the organization. This methods research designed by using the explanatory research. Unit analysis in this research is students in University of Merdeka Malang. The research instrument used questionnaires technique, collected from a sample of 150 students. Data analysis techniques used the SmartPLS and descriptive analysis. This results research showed that Brand Social Responsibility (BSR) does not have an effect on the reputation and competitiveness. The CSR has effect on reputation but not towards competitiveness. The reputation has effect on competitiveness. CSR influences against reputational mediated by competitiveness. Based on the research results, The University of Merdeka Malang should be continue to implement and enhance the BSR and the CSR program in a more planned and ongoing concern as a manifestation of Business and Economics Feculty in improving knowledge, expertise and skills of the nation's children.
\end{abstract} Keywords: Corporate Social Responsibility
Reputation, Competitiveness. (CSR), Brand Social Responsibility (BSR),

\section{PENDAHULUAN}

Kelangsungan organisasi tergantung pada sumber daya yang dimiliki dan strategi apa yang dipilih dalam memberdayakan sumber daya internal itu untuk merespons ancaman dan peluang eksternal (Hit, Ireland dan Hoskisson, 2009). Apabila suatu perusahaan dapat mencocokan sumber daya internalnya dengan peluang lingkungan eksternalnya, atau menggunakannya untuk mengurangi atau menghilangkan dampak ancaman, maka perusahaan tersebut telah mencapai kelayakan strategis. Ini sangat relevan dengan upaya mempertahankan dan meningkatkan kinerja organisasi. Pendapat ini didukung Urban dan Star (1991) yang menyatakan bahwa keberhasilan suatu organisasi dalam mencapai kinerjanya tergantung sejauh mana organisasi tersebut mampu menerapkan strategi yang tepat.

Tidak dapat dipungkiri bahwa keberlangsungan PTS di Indonesia masih tergantung pada sedikit banyaknya mahasiswa yang berhasil diperolehnya. Dengan terpenuhinya student body PTS, maka dimungkinkan untuk berkembang masih tinggi. Dan sebaliknya bagi PTS yang tidak dapat memenuhi student body minimal akan sulit untuk berkembang. Selain itu kurangnya kepercayaan masyarakat untuk menggunakan jasa PTS dalam mendidik putra-putrinya dengan menempatkan PTS di nomor dua setelah PTN, sekaligus persaingan ketat yang tidak hanya dengan sesama PTS namun juga bersaing dengan PTN yang membuka program penerimaan melalui jalur mandiri yang notabene merupakan pasar bagi PTS menjadi tantangan berat bagi PTS dalam menentukan strategi yang tepat.

Jumlah perguruan tinggi swasta (PTS) di wilayah Malang Raya saat ini menunjukkan perkembangan yang sangat pesat. Sampai dengan tahun 2015 Jumlah perguruan tinggi di Malang Raya mencapai 87 perguruan tinggi yang tersebar di Kota Malang sebanyak 62 PT, di Kota Batu 6 PT 
dan 19 PT di Kabupaten Malang. Semakin banyaknya jumlah PTS, maka semakin tinggi tingkat persaingan antar perguruan tinggi. Hal ini merupakan tantangan positif bagi manajemen PTS untuk semakin meningkatkan kualitasnya.

Persaingan yang semakin ketat, menuntut PTS untuk mengaplikasikan strategi pemasaran komersial untuk "menjual" gagasan dalam rangka mengubah perilaku dan persepsi terhadap PTS melalui implementasi prinsip-prinsip manajemen. Selain menerapkan 9 elemen marketing yang yang telah dikenal (segmenting, targetting, positioning, differentiation, marketing mix, selling, brand, service dan process), pada dasarnya marketing menurut Hemawan Kertajaya (2001) diumpamakan sebagai seni "menjual" diri (selling self) atau organisasi. Apabila organisasi menerapkan prinsipprinsip : promosi tanpa memaksa, memahami dan menerapkan positioning secara tepat, memahami branding dan diferensiasi berarti lembaga atau perusahaan telah menjalankan marketing dengan benar.

Sebagai sebuah organisasi jasa yang secara konseptual dibentuk oleh 2 hal, yaitu people based dan equipment based, maka sudah selayaknya PTS merumuskan suatu strategi yang paling tepat untuk menyikapi fenomena tersebut. Oleh karena itu diperlukan pemahaman secara detail sumber keunggulan bersaing yang dimiliki PTS dan perumusan strategi sebagai pembentuk keunggulan posisional dan kinerja PTS, sehingga tetap dapat eksis dalam pengelolaan sumber daya yang akan dimilikinya.

Perumusan dan implementasi strategi yang tepat guna akan diperoleh ketika PTS mempertimbangkan sumber keunggulan bersaing yang terdiri dari superior resource, superior skill, dan superior control merupakan faktor yang tidak dapat ditinggalkan ketika perguruan tinggi akan menetapkan strategi yang tepat guna. Selain itu dalam merumuskan strategi organisasi perlu memandang marketing sebagai sebuah keseluruhan (the whole). Pada masa kini visi, misi dan nilai-nilai organisasi tidak hanya melibatkan intelektualitas (mind) dan hati (heart),melainkan juga ruh (spirit). Penjabaran dapat dilihat pada bagan " 32 Values-Based Matrix". Intinya bahwa, pandanglah marketing sebagai the whole (menyeluruh dan utuh) dan bukan sekadar alat atau diandaikan anggota tubuh.

Dengan menguasai branding dan unsur segitiga pemasaran lainnya yaitu penerapan dasar-dasar marketing sebagai " $3 i$ Marketing Triangle", yaitu positioning (cara sasaran/publik yang hendak diubah perilakunya mendefinisikan perusahaan/ organisasi dengan kompetitor), differentiation (perbedaan) dan brand (keunikan, ketajaman, dan fokus sebuah produk/jasa dibandingkan dengan lainnya, bisa berupa logo dan bentuk unik) diharapkan reputasi dan daya saing akan meningkat.

Peta persaingan dan perkembangan dunia saat ini yang telah mengalami pergeseran nilai menuntut organisasi untuk mengedepankan nilai-nilai sosial (social value) dan peluang bagi organisasi untuk hidup berdampingan secara sinergis. Salah satunya melalui program CSR (Corporate Social Responsibility) sebagai salah satu bentuk strategi marketing yang terus menunjukkan kecenderungan meningkat di dunia global dan di Indonesia. Kesadaran bahwa keuntungan dan keberlangsungan suatu entitas usaha secara jangka panjang hanya bisa diperoleh melalui peningkatan kesejahteraan masyarakat mendorong timbulnya komitmen perusahaan untuk melakukan tanggung jawab sosial (Abidin, 2006). Hal tersebut juga dapat dibuktikan dari survei yang dilakukan oleh 'Global CSR Survey" pada 10 negara, hasilnya mayoritas konsumen (72\%) mengatakan sudah membeli produk dari suatu perusahaan serta merekomendasikan pada yang lain sebagai respon terhadap CSR yang dilakukan perusahaan tersebut. Sebaliknya $61 \%$ dari mereka sudah memboikot produk dari perusahaan yang tidak melakukan program tanggung jawab sosial. Dari survei tersebut dapat disimpulkan, ada pertumbuhan keinginan dari konsumen untuk membeli produk berdasarkan kriteria- kriteria berbasis nilai-nilai dan etika. 
Riset yang dilakukan oleh Roper Search Worldwide dalam Susanto (2007) menunjukkan $75 \%$ responden memberi nilai lebih kepada produk dan jasa yang dipasarkan oleh perusahaan yang memberi kontribusi nyata kepada komunitas melalui program pengembangan. Sekitar 66\% responden juga menunjukkan mereka siap berganti merek kepada merek perusahaan yang memiliki citra sosial yang positif yang didapatkan melalui CSR. Berdasarkan kedua riset tersebut dapat dilihat bahwa CSR dapat menciptakan brand loyalty. Dengan adanya CSR, akan memberikan kesan positif terhadap produk. Hal ini akan membuat sebuah merek menjadi lebih dikenal dan diingat, yang membentuk ikatan emosional di benak konsumen, lama kelamaan ikatan emosional tersebut akan berkembang menjadi brand loyalty yang merupakan bagian dari brand equity (ekuitas merek).

Kecenderungan tersebut bisa dijadikan acuan betapa penting penetapan CSR bagi pembentukan brand equity perusahaan dan meningkatkan loyalitas pelanggan. Dalam kajian ini akan diungkapkan apakah CSR itu, bagaimana CSR dapat mempengaruhi reputasi, bagaimana proses brand equity terbentuk, bagaimana penerapan CSR dalam suatu organisasi sehingga dapat meningkatkan brand equity, apa yang sebaiknya dilakukan agar program CSR nya berhasil dan bagaimana implikasi strategisnya bagi organisasi.

"Brand Social Responsibility" yang menjadi salah satu bentuk pengembangan CSR yang berpedoman pada $3 i$ Marketing Triangle melalui brand Identity, brand Integrity, dan brand Image diharapkan akan menjadi alternatif solusi dalam meningkatkan keunggulan posisional, dan kinerja PTS. Program Corporate Social Responsibility (CSR) yang direncanakan dan dilaksanakan dengan baik (mendukung bisnis inti perusahaan) akan menambah nilai bagi perusahaan sehingga diharapkan dapat menjadi salah satu pemicu timbulnya loyalitas merek. Keberhasilan dari penerapan program CSR diharapkan dapat mencapai sinergi karena merupakan kunci dari konsep pembangunan berkelanjutan (sustainable development).

Agar CSR maupun BSR yang dilakukan bisa benar-benar menjadi marketing tools bagi perusahaan pelaksanaannya harus disesuaikan dengan visi dan misi perusahaan, yang berarti jika program itu berhasil dengan baik pelaksanaannya tidak hanya bertujuan untuk publisitas sesaat saja, tapi harus secara berkesinambungan. Sehingga CSR yang dilakukan dapat menjaga atau meningkatkan daya saing melalui reputasi dan kesetiaan merek produk atau citra perusahaan. Kedua hal tersebut akan menjadi keunggulan kompetitif perusahaan yang sulit untuk ditiru oleh para pesaing. Supaya hal tersebut tercapai investasi dalam CSR harus memperhatikan kecocokan dengan nilai-nilai yang terkandung dalam merek, relevansi dan daya tarik pelanggan, karena mereka percaya investasi pada CSR akan meningkatkan reputasi perusahaan atau merek dan memotivasi karyawan (Knox, Maklan, French, 2005).

Tujuan utama dari penelitian ini mengetahui pengaruh Brand Social Responsibility dan Corporate Social Responsibility sebagai upaya untuk meningkatkan reputasi dan daya saing organisasi terutama di Universitas Merdeka Malang. Diharapkan program ini mampu memberikan manfaat besar bagi stakeholder terutama institusi, mahasiswa dan masyarakat. Sasaran program ini adalah mahasiswa di FEB Universitas Merdeka Malang, dan masyarakat. Sedangkan manfaat kegiatan ini secara umum adalah : 1) Meningkatkan spirit untuk membangun kepedulian terhadap kebutuhan masyarakat dengan membuat program CSR sesuai dengan keahlian dan kapasitas yang dimiliki. 2) Memperkuat reputasi dan daya saing organisasi melalui penganekaragaman program berbasis keahlian dan kapasitas unit organisasi.

\section{METODE PENELITIAN}

Rancangan penelitian ini adalah deskriptif survei dan ekplanatori survei 
(explanation research). Unit analisis dalam penelitian ini adalah mahasiswa di FEB Universitas Merdeka Malang, Populasi dalam penelitian ini adalah mahasiswa di Fakultas Ekonomi dan Bisnis. Dalam penelitian ini proses penarikan sampel minimal dapat dilakukan dengan teknik purposive sampling. Teknik Pengumpulan data yang digunakan dalam penelitian ini melalui penyebaran kuesioner terhadap 150 mahasiswa FEB Universitas Merdeka Malang.

Dalam penelitian ini data primer meliputi informasi mengenai sumber keunggulan bersaing, perumusan strategi, dan kinerja. Hipotesis yang diajukan dalam penelitian ini adalah : a) BSR berpengaruh terhadap Reputasi; b) BSR berpengaruh terhadap daya saing; c) CSR berpengaruh terhadap Reputasi; d) CSR berpengaruh terhadap daya saing; e) Reputasi berpengaruh terhadap daya saing; f) Reputasi memediasi pengaruh BSR dan CSR terhadap daya saing. Pengujian hipotesis dalam penelitian ini menggunakan metode Partial Least Square (PLS). PLS merupakan metode alternatif analisis dengan Structural Equation Modelling (SEM) yang berbasis variance. Keunggulan metode ini adalah tidak memerlukan asumsi dan dapat diestimasi dengan jumlah sampel yang relatif kecil. Alat bantu yang digunakan berupa program SmartPLS Versi3.

\section{Uji Validitas}

Setelah menyebarkan kuesioner kepada 35 responden (pretest), peneliti melakukan uji keakuratan (validitas) dan kekonsistenan (reliabilitas) dengan. Evaluasi Measurement (Outer) Model. Uji ini dilakukan terhadap 4 variabel yang terwakilkan dalam tiap pertanyaan yang ada di dalam kuesioner dan sesuai dengan construct variabel operasional penelitian yaitu Brand Social Responsibility, Corporate Social Responsibility, corporate reputation dan Daya Saing. Suatu indikator dinyatakan valid jika mempunyai loading factor di atas 0,6 terhadap konstruk yang dituju.
Tabel 1. Loading factor indikator

\begin{tabular}{|l|l|l|l|l|}
\hline & BSR & CSRF & DS & RP \\
\hline BSR1 & 0,897 & & & \\
\hline BSR2 & 0,806 & & & \\
\hline BSR4 & 0,764 & & & \\
\hline BSR6 & 0,909 & & & \\
\hline CSRF1 & & 0,850 & & \\
\hline CSRF2 & & 0,787 & & \\
\hline CSRF3 & & 0,764 & & \\
\hline CSRF5 & & 0,743 & & \\
\hline DS1 & & & 0,713 & \\
\hline DS11 & & & 0,779 & \\
\hline DS2 & & & 0,808 & \\
\hline DS3 & & & 0,911 & \\
\hline DS4 & & & 0,824 & \\
\hline DS5 & & & 0,871 & \\
\hline DS6 & & & 0,798 & \\
\hline DS7 & & & 0,878 & \\
\hline DS9 & & & 0,801 & \\
\hline RP1 & & & & 0,817 \\
\hline RP2 & & & & 0,773 \\
\hline RP3 & & & & 0,799 \\
\hline RP4 & & & & 0,912 \\
\hline RP5 & & & & 0,933 \\
\hline RP6 & & & & 0,831 \\
\hline
\end{tabular}

Hasil uji validitas nilai loading factor sebagian besar indikator di atas nilai yang disarankan yaitu sebesar 0,6. Nilai loading factor dibawah 0,6 adalah BSR3, BSR5, CSRF4, DS8 dan DS10. Berarti indikator yang dipergunakan dalam penelitian ini selain indikator 5 indikator tersebut adalah valid atau telah memenuhi convergent validity. Peneliti memutuskan untuk membuang indikator yang nilai loading factor dibawahnya 0,6 adalah BSR3, BSR5, CSRF4, DS8 dan DS10 karena tidak valid. Setelah menghilangkan kelima indikator tersebut hasil yang diperoleh adalah sebagaimana ditunjukkan padal tabel 1 . Tabel di atas menunjukkan bahwa loading factor memberikan nilai di atas nilai yang disarankan yaitu sebesar 0,6. Berarti indikator yang dipergunakan dalam penelitian ini adalah valid atau telah memenuhi convergent validity. 
Metode lain untuk melihat discriminant validity adalah dengan melihat nilai square root of average variance extracted(AVE). Nilai yang disarankan adalah di atas 0,5. Berikut adalah nilai AVE dalam penelitian ini:

Tabel 2. discriminant validity

\begin{tabular}{|c|c|c|c|c|}
\hline & $\begin{array}{l}\text { Cronbach's } \\
\text { Alpha }\end{array}$ & rho_A & $\begin{array}{l}\text { Composite } \\
\text { Reliability }\end{array}$ & AVE \\
\hline BSR & 0,871 & 0,922 & 0,909 & 0,716 \\
\hline CSRF & 0,795 & 0,799 & 0,867 & 0,619 \\
\hline DS & 0,939 & 0,944 & 0,949 & 0,676 \\
\hline RP & 0,920 & 0,937 & 0,938 & 0,716 \\
\hline
\end{tabular}

Tabel 2 memberikan informasi bahwa nilai AVE di atas 0,5 untuk semua konstruk yang terdapat pada model penelitian. Nilai terendah AVE adalah sebesar 0,619 pada konstruk CSRF (Corporate Social Responsibility FEB).

Uji reliabilitas dilakukan dengan melihat nilai composite reliability dari blok indikator yang mengukur konstruk. Hasil composite reliability menunjukkan nilai yang memuaskan jika di atas 0,7. Berikut adalah nilai composite reliability pada output. Tabel di atas menunjukkan bahwa nilai composite reliability untuk semua konstruk adalah di atas 0,7 yang menunjukkan bahwa semua konstruk pada model yang diestimasi memenuhi kriteriadiscriminant validity. Nilai composite reliability yang terendah adalah sebesar 0,867 pada konstruk CSRF (Corporate Social Responsibility FEB) Uji reliabilitas juga bisa diperkuat dengan Cronbach's Alpha. Nilai yang disarankan adalah di atas 0,6 dan pada tabel di atas menunjukkan bahwa nilai Cronbach's Alpha untuk semua kontruk berada di atas 0,6. Nilai terendah adalah sebesar 0,795 yaitu CSRF (Corporate Social Responsibility FEB). Dari 120 kuesioner yang disebar oleh peneliti, 103 layak dipakai sedangkan 17 tidak layak.

\section{HASIL DAN PEMBAHASAN Profil Responden Berdasarkan Jenis Kelamin}

\section{Jenis Kelamin Responden}

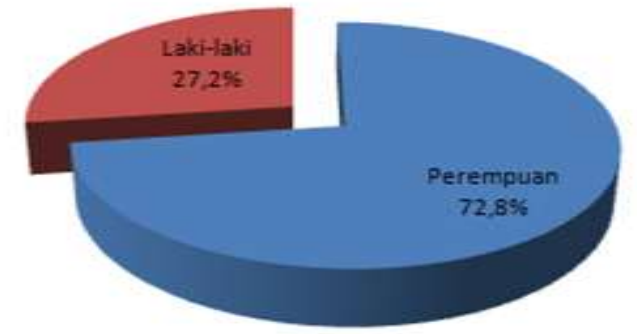

Gambar 1. Jenis kelamin responden

Pada gambar 1, dapat dilihat bahwa 103 responden terdiri atas 28 orang pria dan 75 orang wanita. Dengan kata lain, wanita merupakan mayoritas responden 72,8 persen sedangkan sisanya laki-laki 27,2 persen

\section{Profil Responden Berdasarkan Usia}

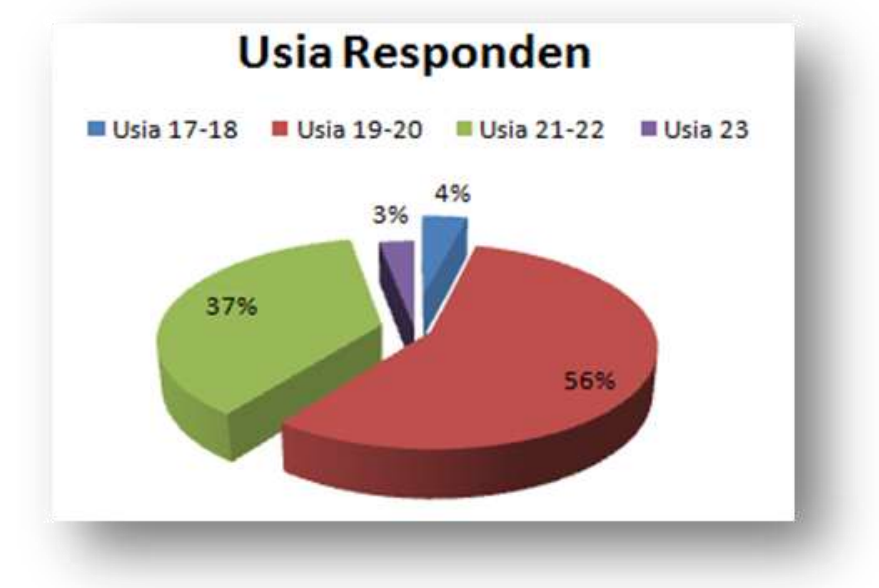

Gambar 2. Usia Responden

Dari gambar 2 dapat dilihat karakteristik umur dari responden penelitian ini. Sekitar 56 persen atau 58 responden memiliki rentang usia mulai dari dibawah 19-20 tahun. Sedangkan, untuk responden penelitian yang memiliki rentang usia 21-22 tahun terdapat sebesar 37 persen atau 38 responden. Kemudian untuk usia 17-18 tahun sebesar 4 persen atau 4 responden. Di samping itu, hanya terdapat 3 orang (3 persen) dari seluruh total responden yang 
memiliki rentang umur 23 tahun.

\section{Program FEB Berbagi dan Peduli}

Program "FEB Berbagi dan Peduli" merupakan program aktivitas pemasaran FEB Unmer Malang yang dirancang sebagai wujud dari kepedulian FEB (CSR) terhadap kebutuhan pengembangan keahlian, pendidikan, keterampilan masyarakat khususnya anak-anak SMA berbasis keahlian dan kapasitas yang dimiliki oleh FEB.

Berdasarkan hasil analisis diketahui bahwa dari seluruh responden yang diteliti menunjukkan bahwa secara keseluruhan responden menyatakan setuju dengan skor rata-rata 5,67 program ini. Skor tertinggi diperoleh pada indikator Aktivitas pemasaran FEB melalui Program "FEB Berbagi dan Peduli" menunjukkan bahwa FEB ingin mengembangkan kemampuan, keahlian dan keterampilan anak bangsa yang lebih baik $(5,97)$ disusul Aktivitas pemasaran FEB melalui Program "FEB Berbagi dan Peduli" menunjukkan FEB memperhatikan pengembangan kemampuan, keahlian dan keterampilan anak bangsa $(5,66)$.

Skor terrendah pada indikator Program "FEB Berbagi dan Peduli" menunjukkan bahwa FEB bersikap adil, penyayang, manusiawi dan peduli terhadap pengembangan kemampuan, keahlian dan keterampilan anak bangsa dalam jangka panjang $(5,50)$. Namun yang perlu dicermati adalah ketidaksetujuan responden pada indikator program FEB Berbagi dan peduli yang secara tulus (mencapai 19,5 persen) dan ingin memperhatikan (mencapai 16,4 persen) pengembangan kemampuan, keahlian dan keterampilan anak bangsa., dan mencapai 18,5 persen untuk indikator FEB bersikap adil, penyayang, manusiawi dan peduli terhadap pengembangan kemampuan, keahlian dan keterampilan anak bangsa dalam jangka panjang. Hal ini berarti kesinambungan dari program sebagai bentuk ketulusan, perhatian dan keadilan serta kepedulian terhadap pengembangan kemampuan, keahlian dan keterampilan anak bangsa dalam jangka panjang masih perlu diupayakan implementasinya. Persepsi tersebut bisa dimaklumi mengingat pelaksanaan program yang masih belum merata dan masih dalam skala kecil.

\section{Corporate Social Responsibility (CSR) FEB}

Corporate Social Resposnsibility (CSR) ini menjadi fenomena strategi perusahaan yang mengakomodasi kebutuhan dan kepentingan stakeholder-nya. CSR timbul sejak era dimana kesadaran akan sustainability perusahaan jangka panjang adalah lebih penting daripada sekedar profitability (Khairandy, 2008). Adanya program CSR ini juga dalam perkembangannya dapat memberikan imej tertentu bagi konsumen, stakeholder, dan masyarakat umum akan dampak adanya CSR tersebut. Elkington mengemas konsep CSR ke dalam tiga elemen, yaitu: people, profit, dan planet, disingkat menjadi $3 \mathrm{P}$. Melalui konsep ini Elkingkton berusaha menekankan bahwa perusahaan sebaiknya tidak hanya mengejar keuntungan (profit), namun perusahaan juga perlu memperhatikan dan telibat dalam pemenuhan kesejahteraan masyarakat (people) dan turut berkontribusi dalam menjaga kesehatan lingkungan (planet).

Hasil analisis tentang program CSR yang dilakukan oleh FEB menunjukkan bahwa secara keseluruhan responden menyatakan setuju dengan skor rata-rata 5,59 terhadap program CSR FEB. Skor tertinggi diperoleh pada indikator Aktivitas "FEB Berbagi dan Peduli" yang dilakukan dapat memberikan dampak yang baik bagi pengembangan kemampuan, keahlian dan keterampilan anak bangsa $(5,87)$ disusul Aktivitas "FEB Berbagi dan Peduli" yang dilakukan dapat membantu meningkatkan kemampuan, keahlian dan keterampilan anak bangsa $(5,75)$. Skor terrendah pada indikator FEB telah dengan tulus dan berkelanjutan menunjukkan kepedulian pada pengembangan kemampuan, keahlian dan keterampilan anak bangsa $(5,24)$.

Hal yang perlu dicermati adalah ketidaksetujuan responden pada indikator 
FEB merupakan institusi yang peduli pada pengembangan kemampuan, keahlian dan keterampilan anak bangsa (mencapai 18,5 persen) dan indikator FEB telah dengan tulus dan berkelanjutan menunjukkan kepedulian pada pengembangan kemampuan, keahlian dan keterampilan anak bangsa (mencapai 21,3 persen). Hal ini berarti ketulusan dan kepedulian terhadap pengembangan kemampuan, keahlian dan keterampilan anak bangsa dalam jangka panjang masih diragukan sehingga perlu ditingkatkan implementasinya.

\section{Reputasi Perusahaan}

Reputasi perusahaan sering digambarkan sebagai keunggulan kompetitif yang dimiliki perusahaan (Deephouse, 2000). Reputasi perusahaan yang baik dapat membedakan perusahaan dari pesaingnya dan merupakan aset strategik yang penting untuk sebuah perusahaan karena tidak hanya memiliki potensi penciptaan nilai, tetapi juga karena karakter tidak berwujudnya yang membuat sulit perusahaan pesaingnya untuk meniru (Fombrun \& Shanley, 1990; Roberts \& Dowling, 2002 dalam Lai, Chiu, Yang, Pai, 2010).

Faktor yang mempengaruhi corporate reputation dibagi dua oleh Lines (2003) dalam Weiwei (2007) yaitu internal faktor yang mempengaruhi reputasi perusahaan adalah komunikasi, transparansi, nilai kemanusiaan, perlakukan terhadap karyawan, kemampuan untuk berinovasi, reputasi CEO perusahaan, kemampuan untuk beradaptasi dan menghadapi masalah sosial dan lingkungan (CSR). Sedangkan faktor eksternal yang dapat mempengaruhi reputasi perusahaan adalah konsumen, media cetak dan televisi, analisis keuangan, shareholder, analisis industri, hukum dan pemerintahan.

Hasil pengukuran terhadap reputasi perusahaan menunjukkan bahwa dari seluruh responden yang diteliti menunjukkan bahwa secara keseluruhan responden menyatakan setuju terhadap seluruh indikator dalam setiap dimensi karena skor rata-rata diatas 5 .

\section{Daya Saing Organisasi}

Hasil pengukuran terhadap reputasi perusahaan menunjukkan bahwa dari seluruh responden yang diteliti menunjukkan bahwa secara keseluruhan responden menyatakan setuju terhadap seluruh indikator dalam setiap dimensi karena skor rata-rata diatas 5 .

\section{Pengujian Model Struktural (Inner Model)}

Setelah model yang diestimasi memenuhi criteria Outer Model berikutnya dilakukan pengujian model structural (Inner model). Berikut adalah nilai R-Square pada konstruk.

Tabel 3. pengujian model structural (Inner model).

\begin{tabular}{|l|r|r|}
\hline & R Square & $\begin{array}{l}\text { R Square } \\
\text { Adjusted }\end{array}$ \\
\hline DS & 0,705 & 0,696 \\
\hline RP & 0,297 & 0,282 \\
\hline
\end{tabular}

Tabel di atas memberikan nilai 0,705 untuk konstruk DS yang berarti bahwa RP mampu menjelaskan varians DS sebesar $70,5 \%$. Nilai R juga terdapat pada RP yang dipengaruhi oleh BSR dan CSRF yaitu sebesar 0,297 yang berarti bahwa BSR dan CSRF mampu menjelaskan varians $\mathrm{RP}$ sebesar $29,7 \%$.

\section{Pengujian Hipotesis}

Tabel 4. Hasil Pengujian hipotesis

\begin{tabular}{|l|r|r|r|r|r|}
\hline & $\begin{array}{l}\text { Original } \\
\text { Sample } \\
\text { (0) }\end{array}$ & $\begin{array}{l}\text { Sample } \\
\text { Mean (M) }\end{array}$ & $\begin{array}{l}\text { Standard } \\
\text { Deviation } \\
\text { (STDEV) }\end{array}$ & $\begin{array}{l}\text { T Statistics } \\
\text { (|O/STDEV) })\end{array}$ & $\begin{array}{l}\text { P } \\
\text { Values }\end{array}$ \\
\hline BSR $>$ DS & 0,016 & 0,036 & 0,093 & 0,168 & 0,866 \\
\hline BSR $>$ RP & 0,138 & 0,113 & 0,185 & 0,749 & 0,454 \\
\hline CSRF $>$ DS & 0,151 & 0,132 & 0,097 & 1,551 & 0,121 \\
\hline CSRF $>$ RP & 0,433 & 0,465 & 0,154 & 2,818 & 0,005 \\
\hline RP $>$ DS & 0,740 & 0,744 & 0,062 & 11,876 & 0,000 \\
\hline
\end{tabular}

Tabel 4 menunjukkan bahwa hubungan antara BSR dengan DS adalah tidak signifikan dengan T-statistik sebesar 0,168 $(<1,96)$. Nilai original sample estimate adalah positif yaitu sebesar 0,016 yang menunjukkan bahwa arah hubungan antara BSR dengan DS adalah positif. Dengan 
demikian hipotesis yang menyatakan bahwa 'BSR berpengaruh terhadap DS' ditolak.

Brand Social Responsibility ini sebagai strategi pemasaran ini juga dapat meningkatkan competitive advantage, brand awareness, membangun kredibilitas merek, meningkatkan imej perusahaan, dan menstimulasi niat konsumen untuk membeli suatu produk (Chattananon, et al, 2007). Aktivitas pemasaran ini memiliki keunggulan kompetitif dibanding dengan pelaksanaan strategi pemasaran yang biasa. Melalui pelaksanaan $B S R$ menunjukkan komitmen perusahaan untuk memberikan nilai „tambahe kepada masyarakat selain membuat lebih terdengar "gaung" aktivitas pemasarannya di konsumen dan masyarakat dibanding kompetitor. Kegiatan yang juga terus dilakukan secara rutin dan terus memberi kebaikan pada konsumen dan masyarakat diharapkan dapat menimbulkan citra yang positif. Sehingga, aktivitas pemasaran yang bersifat sosial dan positif ini pun dapat meningkatkan brand image di masyarakat.

Tabel 4 menunjukkan bahwa hubungan antara BSR dengan RP adalah tidak signifikan dengan T-statistik sebesar 0,749 (< 1,96). Nilai original sample estimate adalah positif yaitu sebesar 0,138 yang menunjukkan bahwa arah hubungan antara BSR dengan RP adalah positif. Dengan demikian hipotesis yang menyatakan bahwa 'BSR berpengaruh terhadap RP' ditolak. Hipotesis ini berdasarkan asumsi yang terkait dengan perilaku konsumen bahwa adanya persepsi konsumen yang positif terhadap produk yang dipasarkan secara bertanggung jawab secara sosial oleh perusahaan dapat meningkatkan reputasi dan kepercayaan konsumen pada perusahaan tersebut. Namun, tampaknya hal tersebut berbeda dengan hasil penelitian. Akibatnya, masyarakat tidak melihat keterkaitan secara langsung antara aktivitas pemasaran secara sosial dengan imej dan reputasi. Hal ini bisa terjadi jika kampanye program belum dilakukan secara terstruktur dan berkelanjutan serta belum menjangkau secara luas.
Tabel 4 menunjukkan bahwa hubungan antara CSRF dengan DS adalah signifikan dengan T-statistik sebesar 1,551 $(<1,96)$. Nilai original sample estimate adalah positif yaitu sebesar 0,151 yang menunjukkan bahwa arah hubungan antara CSRF dengan DS adalah positif. Dengan demikian hipotesis yang menyatakan bahwa 'CSRF berpengaruh terhadap DS' ditolak. Adanya penelitian dari Ellen (2013) yang menyebutkan bahwa kegiatan CSR memiliki pengaruh yang positif dalam beberapa kategori produk terhadap evaluasi konsumen dan intensitas pembelian atas suatu produk/perusahaan. Peran dari perusahaan untuk ikut serta bertanggung jawab terhadap masalah sosial dalam melaksanakan aktivitas perusahaan dan pemasarannya maka dapat menimbulkan penilaian yang positif dari para stakeholder perusahaan tersebut termasuk para konsumen. Selanjutnya konsumen akan lebih menyenangi dan akan lebih mudah mempercayai janji merek yang disampaikan oleh produk yang dinilai peduli terhadap masalah sosial. Dengan demikian, hasil ini menunjukkan bahwa komitmen perusahaan untuk berkontribusi secara sosial dapat meningkatkan brand image produk yang dihasilkan oleh perusahaan. Dan apabila brand image suatu produk telah mempunyai imej yang positif di mata konsumen dan masyarakat maka dapat membangun dan meningkatkan loyalitas merek dari konsumen tersebut (brand loyalty) (Aaker, 2000) tapi tidak demikian dengan pengaruhnya terhadap daya saing. Untuk meningkatkan daya saing tinggi tidak hanya melalui kegiatan CSR namun diperlukan faktor lainnya yang secara langsung berdampak pada daya saing.

Tabel 4 menunjukkan bahwa hubungan antara CSRF dengan RP adalah signifikan dengan T-statistik sebesar 2,818 (> 1,96). Nilai original sample estimate adalah positif yaitu sebesar 0,433 yang menunjukkan bahwa arah hubungan antara CSRF dengan RP adalah positif. Dengan demikian hipotesis yang menyatakan bahwa 'CSRF berpengaruh terhadap RP' diterima. Kepedulian FEB yang mengedepankan CSR 
sebagai salah satu tanggung jawab perusahaan ke masyarakat mendorong adanya penilaian yang positif dari konsumen dan masyarakat. Kegiatan CSR yang dilakukan akan dinilai oleh konsumen bahwa perusahaan tersebut mempunyai kepedulian pada masalah sosial. Hal ini terlihat pada hasil pengujian model pengukuran di mana nilai muatan faktor standar konstruk RP (Reputasi Perusahaan) rata-rata bernilai cukup tinggi yaitu dari 0.81 hingga 0.86 . Hasil ini membuktikan bahwa aktivitas CSR yang dilakukan perusahaan dapat mempengaruhi penilaian konsumen akan perusahaan tersebut.

Keinginan dan kemampuan perusahaan untuk dapat memberikan nilai tambah bagi konsumen sekaligus memenuhi harapan konsumen dengan memberikan pelayanan kepada konsumen dengan baik, menjadi mitra terpercaya bagi pelanggan dan perusahaan yang memiliki kesadaran sosial maka dapat meningkatkan penilaian yang positif perusahaan tersebut di mata konsumen. Penilaian positif ini akhirnya dapat meningkatkan imej dan reputasi perusahaan yang lebih baik. Dan reputasi perusahaan yang baik akan mendorong timbulnya loyalitas konsumen terhadap produk perusahaan tersebut. Hal ini didukung oleh adanya penelitian dari Becker-Olsen et al. (2006) menyatakan bahwa kegiatan Corporate Social Responsibility mempunyai pengaruh yang positif pada persepsi konsumen terkait kredibilitas dan reputasi perusahaan ketika perusahaan melakukan kegiatan CSR yang sejalan dengan bisnis operasionalnya.

Selain itu Keller and Aaker (1998) juga menemukan bahwa keteribatan perusahaan dalam issue lingkungan dan komunitas secara signfikan dapat meningkatkan kredibilitas dan reputasi perusahaan termasuk kepercayaan dan keahlian yang dinilai baik oleh masyarakat. Dengan melakukan kegiatan CSR, maka perusahaan tersebut dapat dianggap ikut serta dan berkontribusi serta bertanggung jawab dalam segala aktivitas perusahaan khususnya pada aktivitas perusahaan (operasional) yang ditujukan ke konsumen dan masyarakat. Hal ini pun dapat meningkatkan redibilitas perusahaan serta citra yang positif dari masyarakat kepada reputasi perusahaan tersebut. Selain itu, dengan adanya publikasi yang positif dari media yang meliput pelaksanaan CSR perusahaan seperti di media cetak, ataupun media elektronik juga dapat meningkatkan reputasi perusahaan tersebut. Chalal \& Sharma (2006) menjelaskan bahwa publikasi positif dari media mengenai pelaksanaan CSR perusahaan dapat meningkatkan nilai merek dan reputasi perusahaan

Tabel 4 menunjukkan bahwa hubungan antara RP dengan DS adalah signifikan dengan T-statistik sebesar 11,866 (> 1,96). Nilai original sample estimate adalah positif yaitu sebesar 0,777 yang menunjukkan bahwa arah hubungan antara RP dengan DS adalah positif. Dengan demikian hipotesis yang menyatakan bahwa 'RP berpengaruh terhadap DS' diterima. Adanya penemuan dalam penelitian menunjukkan bahwa keunggulan reputasi yang dimiliki perusahaan akan meningkatkan daya saing dan mendorong suksesnya pemasaran produk yang ditawarkan oleh perusahaan.

Pada akhirnya, dengan dilakukannya aktivitas pemasaran BSR dan CSR dapat mempengaruhi brand image yang baik dari produk yang nantinya dapat meningkatkan kinerja perusahaan secara keseluruhan termasuk meningkatkan kinerja keuangan dari perusahaan dan akhirnya juga berpengaruh pada reputasi perusahaan dan daya saing yang lebih baik.

Berikut adalah diagram nilai $\mathrm{T}$ statistic berdasarkan output dengan SmartPLS:

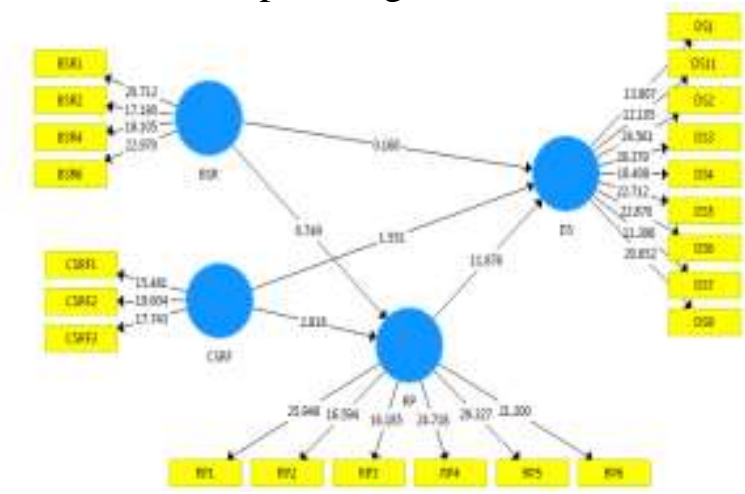

Gambar 3 . Output Bootstrapping 
Jika dilihat dari peran mediasi reputasi perusahaan terhadap pengaruh BSR dan CSR menunjukkan bahwa reputasi perusahaan tidak memediasi pengaruh BSR terhadap daya saing dengan $\mathrm{T}$-statistik sebesar $0,459(<1,96)$, sebaliknya reputasi perusahaan memediasi secara penuh pengaruh CSR terhadap daya saing dengan T-statistik sebesar 2,718 (> 1,96).

\section{PEMBAHASAN}

Temuan penelitian ini menunjukkan bawah meskipun dari hasil penelitian didapatkan ada empat hipotesis yang ditolak yaitu bahwa Brand Social Responsibility (BSR) tidak mempunyai pengaruh langsung terhadap reputasi perusahaan dan daya saing, reptutasi perusahaan tidak memediasi pengaruh langsung terhadap BSR terhadap daya saing dan CSR tidak mempunyai pengaruh langsung terhadap daya saing, maka pelaksanaan BSR dan CSR perlu diupaya secara terus menerus agar dapat memperkuat citra dari merek tersebut (brand image).

Dengan brand image yang kuat pada individual brand seperti maka nantinya dapat mempengaruhi citra perusahaan dari produsen merek tersebut, dalam hal ini Unmer Malang. Maka dari itu pelaksanaan BSR sebaiknya tetap dijalankan oleh perusahaan sebagai suatu strategi pemasaran yang baik, karena selain dapat memberikan suatu konstribusi secara sosial kepada konsumen dan masyarakat juga dapat meningkatkan brand image yang baik dari produk perusahaan dan melalui brand image yang baik tersebut akhirnya dapat meningkatkan corporate reputation daya saing.

Hasil penelitian ini memberikan kontribusi terkait dengan konsep BSR dalam kaitannya dengan Socially Responsible Marketing dan Corporate Social Responsibility. Konsep BSR adalah merupakan turunan dari konsep Socially Responsible Marketing merupakan konsep yang diperkenalkan oleh Kotler dalam Holistic Marketing (Kotler \& Keller, 2009) dan CSR mengenai kepeduliannya pada masalah sosial menjadi pemicu (antecedent) dari reputasi, sementara daya saing menjadi konsukuensi (consequence) dari reputasi.

Bagi perusahaan dengan melaksanakan aktivitas BSR dan CSR pun sebagai satu kesatuan dan berkelanjutan dapat menjadikan dua hal tersebut sebagai keunggulan kompetitif bagi perusahaan dan juga dapat menunjukkan kepada konsumen bahwa perusahaan pun tidak semata-mata hanya mencari profit belaka, namun juga peduli pada masalah yang terjadi di masyarakat. Pada akhirnya dengan melakukan kedua aktivitas tersebut dapat meningkatkan kredibilitas dan reputasi perusahaan di mata konsumen sebagai salah satu stakeholder yang penting bagi perusahaan

\section{PENUTUP}

BSR dan CSR dengan kepeduliannya pada masalah sosial mempunyai peran dalam meningkatkan corporate reputation. Dengan brand image yang baik, brand equity yang meningkat, serta corporate reputation yang baik maka dapat mempengaruhi konsumen dalam keputusan memilih produk dan meningkatkan konsumen untuk dapat masuk ke dalam tahap loyalitas terhadap produk dengan merek tersebut. Temuan dari penelitian ini juga menunjukkan faktorfaktor yang dapat mempengaruhi daya saing, baik secara langsung ataupun secara tidak langsung (melalui mediasi). Hubungan secara langsung terhadap daya saing dipengaruhi oleh variabel CSR. Hubungan secara langsung terhadap reputasi perusahaan dipengaruhi oleh variabel CSR. Sedangkan, yang secara tidak langsung, Bahwa reputasi perusahaan menjadi mediasi antara CSR dan daya saing.

Dengan melihat pelaksanaan BSR yang sudah cukup baik berjalan, tampaknya Unmer Malang dapat meneruskan dan meningkatkan kinerja aktivitas pemasaran secara sosial ini. Unmer Malang dapat melaksanakan komponen lain dari BSR di samping memberi manfaat untuk komunitas seperti dalam hal legal, etika, lingkungan. Contoh dari hal ini antara lain bahwa Unmer 
Malang dalam pemasaran produknya dapat memperkuat pelaksanaan BSR dalam menciptakan dan memperbanyak jenis dari berbagai unit kerja. Terkait pelaksanaan CSR maka perusahaan dapat membangun reputasi perusahaan yang lebih kuat dari pelaksanaan social responsibility yang lebih luas dan variatif. Dalam hal ini, dapat melakukan upaya lainnya dapat melakukan cause promotion yaitu dengan melakukan pengumpulan dana untuk mendukung mengatasi masalah sosial di sekitar perusahaan, ataupun seperti community volunturing di mana dari pihak intern seperti karyawan turut serta menjadi relawan.

Pelaksanaan dari berbagai jenis CSR yang beragam yang dapat dilaksanakan tentunya dapat meningkatkan reputasi perusahaan di mata masyarakat. Memperkuat brand building dari perusahaan yang banyak mempunyai individual brand (unit kerja) sangatlah penting, terlebih berdasarkan hasil beberapa penelitian terbukti bahwa suatu brand dapat menjadi mediasi dari pelaksanaan suatu pemasaran sosial dengan reputasi perusahaan tersebut.

Dengan brand building yang kuat kemudian dilakukan strategi pemasaran yang tepat sasaran dan memberikan manfaat kepada konsumen maka dapat menimbulkan brand image yang baik. Dari brand image yang baik diharapkan reputasi perusahaan pun dapat lebih meningkat di mata konsumen dan masyarakat. Apabila melihat pelaksanaan CSR di mana dari hasil penelitian mempunyai pengaruh positif terhadap reputasi, maka memang sebaiknya aktivitas BSR dan juga CSR ini dapat dilakukan dengan tulus, berjalan secara berkelanjutan dan juga memberi manfaat jangka panjang yang nyata kepada konsumen dan masyarakat. Di samping itu dari manfaat menerapkan BSR dan CSR dengan menunjukkan kepedulian terhadap masalah sosial, maka dapat meningkatkan brand image suatu produk dan mendorong penilaian yang positif dari konsumen.

\section{DAFTAR PUSTAKA}

Aaker, David A and Joachimsthaler. (2000). Brand leadership. The Free Press.

Abidin, Miranty (2006), "CSR di Indonesia" Dalam MIX III (10):17, Jakarta.

Becker-Olsen, K.L., Cudmore, A., \& Hill, R.P. (2006). The impact of perceived corporate social responsibility on consumer behavior. Journal of Business Research, 59, 46-53.

Chalal, H., and Sharma, R.D. (2006). Implications of corporate social responsibility on marketing performance: A conceptual framework. Journal of Services Research, Vol 6 (1), 205-216.

Chattananon, Apisit; Lawley, Meredith; Trimetsoontorn Jirasek;

Supparerkchaisakul, Numchai; Leelayouthayothin, Lackana., 2007. Building corporate image through societal marketing program, Emerald Group Publishing Limited, 230-252.

Deephouse, David L. 2000. Media Reputation as a Strategic Resource: An Integration of Mass Communication and Resource-Based Theories. Lousiana State University, USA

Ellen, P.S., Mohr, L.A. and Webb, D.J. (2000), Charitable is a company known programs and the retailer: do they mix?, Journal of Retailing, Vol. 76 (3), 393-406.

Fombrun, Charles J 1996, Reputation, Realizing Value From the corporate image

Hit, Ireland dan Hoskisson, 2009, Strategic Management Competitiveness nd Understanding Business Strategy, 2nd edition South- Western Cengage Learning

Jamali, Dima and Ramez Mirshak. 2006. Corporate Social Responsibility (CSR): Theory and Practice in a Developing Country Context. Springer: Vol. 7(2)

Keller, K.L., \& Aaker, D.A. (1998). The impact of corporate marketing on acompany's brand extensions. 
Corporate Reputation Review, 1, 356-378.

Kertajaya, Hermawan, 2013 "Marketing: Into Innovation and Technology. The World is Shaking, Indonesia is Standing. How about You?" MarkPlus Conference 2013

Khairandy, R., 2008. Corporate social resposibility dari shareholder ke stakeholder dan dari etika bisnis ke norma hukum, Norwegian Centre for Human Rights.

Knox, Simon; Maklan, Stan and French, Paul., 2005. Corporate Social Responsibility: Exsploring

Stakeholder Relationships and Programe Reporting across Leading FTSE Companies. Journal of Business Ethics, Vol. 61, No. 1, Sep, pp. 7-28.

Kotler, Philip. 2009. Manajemen Pemasaran.Jakarta : Erlangga

Kotler, Phillip and Keller, A Lane. (2009). Marketing management 14th edition. Pearson Education Limited.

Lai, Shiun-Chi, Chiu, Jen-Chih, Yang, FangCin, Pai, Chang-Da. (2010). The effects of Corporate social responsibility on brand performance: The mediating effect of industrial brand cquity and Corporate reputation. Journal of Business Ethics, Vol 95, 457-469.

Porter, M., Kramer, M. (2006). "Strategy and society: the link between competitive advantage and corporate social responsibility". Harvard Business Review.

Susanto, A.B. 2007. Corporate Social Responsibility. The Jakarta Consulting Group Partner In Change. Jakarta.

Urban dan Star, 1991. Advanced Marketing Strategy : Phenomena Analysis and Decision : Prentice Hall.

Weiwei, Tang. 2007. Impact of corporate social image and corporate reputation on customer loyalty: A Review, Management Science and Engineering, Vol 1 (2), 57-62. 